\title{
HUBUNGAN AGRESSIVE DRIVING BEHAVIOR PENGEMUDI SEPEDA MOTOR DENGAN KECELAKAAN LALU LINTAS (STUDI PADA SISWA SMA DI KABUPATEN SIDOARJO)
}

\author{
Mazroh Ilma Soffania \\ Departemen Epidemiologi,Fakultas Kesehatan Masyarakat \\ Universitas Airlangga \\ Alamat korespondensi: Mazroh Ilma Soffania \\ E-mail: ilmamazroh@gmail.com
}

\begin{abstract}
Road traffic accident was the public health problem that can decrease public health status. Most of the road traffic acccident involving motorcyclist and mostly among people around 15-19 years old. Agressive driving behavior was one of the factors causing road traffic accidents. The aim of this study to analize the relationship between motorcyclist's agressive driving behavior with road traffic accidents. This research was analytic observational research with case-control design. The population was senior high school student who riding motorcycle aged $\geq 17$ years old in Kabupaten Sidoarjo. Population were divided into two groups, namely case group and control group. Case group were respondents who had road traffic accidents while control group were respondents who never had a road traffic accidents in the last year. The number of respondens were involved 24 respondents in case group and 48 respondents in control group. Sampling were purposive sample in case group and matching sampling in control group by age and sex. The result of analysis using chi-square test $(\alpha=5 \%)$ showed that agressive driving behavior in motorcyclist has significant relationship of road traffic accidents ( $p=$ 0,0006; OR= 5,320). Senior high school students were encouraged to managed time and more prioritised safety while driving to avoid traffic accidents.
\end{abstract}

Keywords: agressive driving behavior, senior high school, road traffic accident

\begin{abstract}
ABSTRAK
Kecelakaan lalu lintas merupakan masalah kesehatan masyarakat yang dapat menurunkan derajat kesehatan masyarakat. kecelakaan lalu lintas paling banyak melibatkan pengemudi sepeda motor dan sering terjadi pada usia 15-19 tahun. Kebiasaan agresif mengemudi merupakan salah satu faktor penyebab kecelakaan lalu lintas. Tujuan penelitian ini adalah untuk menganalisis hubungan agressive driving behavior pada pengemudi sepeda motor dengan kecelakaan lalu lintas. Penelitian ini merupakan penelitian observasional analitik dengan desain kasus-kontrol. Populasi penelilitian ini adalah siswa SMA yang mengemudi sepeda motor berusia lebih dari sama dengan 17 tahun di Kabupaten Sidoarjo. Populasi dibagi menjadi dua kelompok yaitu kelompok kasus dan kelompok kontrol. Kelompok kasus adalah responden yang pernah mengalami kecelakaan lalu lintas sedangkan kelompok kontrol adalah responden yang tidak pernah mengalami kecelakaan lalu lintas dalam 1 tahun terakhir. Jumlah responden yang dilibatkan sebanyak 24 responden pada kelompok kasus dan 48 responden pada kelompok kontrol. Pengambilan sampel menggunakan purposive sample pada kelompok kasus dan matching sample pada kelompok kontrol berdasarkan usia dan jenis kelamin. Hasil analisis menggunakan chi-square $(\alpha=$ $5 \%)$ menunjukkan ada hubungan antara agressive driving behavior pada pengemudi sepeda motor dengan kecelakaan lalu lintas $(p=0,0006 ; O R=5,320)$. Siswa SMA dihimbau untuk lebih memanajemen waktu dan lebih mempriorotaskan keselamatan saat mengemudi di jalan raya untuk menghindari kecelakaan lalu lintas.
\end{abstract}

Kata kunci: kebiasaan agresif mengemudi, siswa SMA, kecelakaan lalu lintas

\section{PENDAHULUAN}

Kecelakan lalu lintas merupakan masalah kesehatan masyarakat yang termasuk dalam penyakit tidak menular. Kecelakaan lalu lintas menimbulkan dampak negatif dan dapat menurunkan derajat kesehatan masyarakat. Global Status Report on Road Safety menyebutkan bahwa sekitar 1,25 juta korban meninggal dan 20-50 juta lainnya mengalami luka akibat kecelakaan lalu 
lintas, angka tersebut menetap sejak tahun 2007. WHO menyatakan bahwa kecelakaan lalu lintas di Indonesia menjadi pembunuh ketiga setelah penyakit tuberculosis dan jantung (Badan Intelijen Negara, 2013).

Kecelakaan lalu lintas menurut undang-undang nomor 22 tahun 2009 tentang lalu lintas dan angkutan jalan adalah suatu peristiwa yang tidak disegaja di jalan raya yang melibatkan kendaraan dengan atau tanpa pengguna jalan lain dan mengakibatkan korban manusia dan kerugian harta benda. Indonesia mengalami peningkatan jumlah kecelakaan lalu lintas setiap tahunnya. Banyaknya angka kecelakaan lalu lintas di Indonesia seiring dengan jumlah kendaraan bermotor yang terus meningkat. Peningkatan jumlah kendaraan jenis sepeda motor memiliki angka paling tinggi.

Data Polantas (2013) menunjukkan bahwa terdapat penigkatan jumlah kecelakaan lalu lintas dari tahun 2013 ke tahun 2016. Angka kejadian kecelakaan lalu lintas menunjukkan sebanyak 100.106 kejadian pada tahun 2013 dan 104.522 kejadian pada tahun 2016 (Korlantas Polri, 2014). Data statistik Korlantas Polri menyebutkan selama tahun 2016 terdapat dari 104.552 kejadian kecelakaan lalu lintas dengan jumlah kematian 22.213 jiwa. Jumlah kerugian lebih dari 48 miliyar rupiah selama periode januari sampai maret 2017 (Korlantas Polri, 2017).

Data statistik WHO menyebutkan bahwa pada tahun 2013 angka kematian akibat kecelakaan lalu lintas di Indonesia adalah sebesar 38.279 dan $36 \%$ diantaranya adalah pengemudi dan penumpang kendaraan beroda dua (WHO, 2016). Di Indonesia, kecelakaan sepeda motor merupakan penyumbang terbanyak kejadian kecelakaan lalu lintas. data statistik Korlantas Polri (2017) menunjukkan bahwa sepeda motor merupakan angka terbanyak penyumbang kejadian kecelakaan lalu lintas dalam dua triwulan periode di akhir tahun 2016 dan awal tahun 2017 yaitu sebanyak 63.251 kejadian.

Data WHO (2013) menyebutkan bahwa hampir 60\% kematian karena kecelakaan lalu lintas pada tingkat global terjadi pada usia antara 15-44 tahun dan lebih dari 300.000 kematian pada kalangan usia 15-29 tahun (World Health Organization, 2016). Di Indonesia kecelakaan lalu lintas paling banyak terjadi pada usia antara 15-19 tahun dengan angka sebesar 4414 orang pada tahun 2017 (Korlantas Polri, 2017). Kabupaten Sidoarjo merupakan wilayah dengan angka kecelakaan tertinggi kedua di Jawa Timur setelah kabupaten kediri dengan angka kejadian 1287 korban (Badan Pusat Statistik, 2013).

$$
\text { Penyebab utama terjadinya }
$$

kecelakaan lalu lintas berdasarkan Haddon's Matrix terdiri dari tiga faktor yaitu faktor manusia, faktor lingkungan, dan faktor kendaraan yang terbagi menjadi tiga tahap yaitu pada tahap pra kecelakaan, tahap saat kecelakaan, dan pascakecelakaan. Tahap pra-kecelakaan bertujuan untuk mencegah terjadinya kecelakaan dalam hal ini upaya yang dilakukan adalah upaya promotif dan preventif untuk meminimalisir terjadinya kecelakaan lalu lintas.

Tahap saat kecelakaan bertujuan untuk pencegahan cedera dalam hal ini upaya yang dilakukan adalah upaya kuratif dan pertolongan pertama terhadap korban kecelakaan. Tahap pasca-kecelakaan bertujuan untuk mempertahankan hidup dimana upaya yang dilakukan adalah rehabilitasi terhadap korban kecelakaan. Pengetahuan, keterampilan dan perilaku pengemudi di jalan raya merupakan komponen yang tergolong faktor manusia tahap pra-kecelakaan berdasarkan Haddon's Matrix (Mohan, dkk., 2006).

Faktor manusia merupakan faktor dominan penyebab kecelakaan menurut Direktorat Jendral Perhubungan Darat. Besarnya persentase masing-masing faktor penyebab kecelakaan lalu lintas dan angkutan jalan di Indonesia tahun 2010- 
2016 antara lain faktor manusia dengan persentase $69,70 \%$, faktor sarana atau kendaraan sebesar $21,21 \%$ dan faktor prasarana atau jalan sebesar 9,09\% (KNKT, 2016).

Perilaku dan mental dari pengguna jalan termasuk pengemudi kendaraan bermotor merupakan faktor yang berpengaruh terhadap stabilitas lalu lintas. Etika, sopan santun, toleransi antar pengguna jalan, kematangan emosi dan kepedulian pengguna jalan di jalan raya akan menimbulkan interaksi yang dapat mewarnai situasi lalu lintas yang dapat menciptakan situasi aman dan selamat saat mengemudi serta berpengaruh pada kelancaran lalu lintas (Danang, 2010).

Disiplin Berlalu lintas menurut Undang-Undang Nomor 22 Tahun 2009 tentang Lalu Lintas dan Angkutan Jalan adalah segala perilaku pengguna jalan baik bermotor maupun tidak bormotor, di jalan raya yang sesuai dengan undang-undang ataupun peraturan lalu lintas yang telah ditetapkan. Disiplin mengemudi memiliki kaitan dengan kebiasaan atau tindakan agresif mengemudi. Dimana pengemudi yang memiliki kebiasaan agresif mengemudi cenderung sering melanggar peraturan lalu lintas.

Agressive driving behavior atau kebiasaan agresif mengemudi merupakan tindakan yang dilakukan secara sengaja dalam mengemudi yang cenderung dapat meningkatkan risiko kecelakaan lalu lintas yang dimotivasi oleh ketidaksabaran, kekesalan, permusuhan, dan atau upaya untuk menghemat waktu (Tasca, 2000). Aggressive driving behavior dapat dikatakan sebagai pola disfungsi dari perilaku sosial yang mengganggu keamanan publik. Agressive driving behavior terdiri dari kebiasaan membuntuti kendaraan lain (tailgaiting), mengaklakson dalam keadaan yang tidak dibutuhkan (honking), melakukan gerakan yang membahayakan pengemudi lain (rude gesturing) dan mengedipkan lampu jauh di suasana yang tenang (flashing light) (Houston, et al, 2003).
Faktor yang mempengaruhi aggressive driving behavior yaitu usia, jenis kelamin, keterampilan mengemudi, lingkungan, gaya hidup dan kepribadian pengemudi (Tasca, 2000). Aggressive driving behavior yang tinggi sebagian besar melibatkan pengemudi laki-laki dengan usia antara 17-35 tahun, sedangkan perempuan menunjukkan tingkat Aggressive driving behavior yang lebih rendah (Tasca, 2000). Keterampilan mengemudi dapat ditunjukkan dengan pengalaman seorang pengemudi dalam mengemudi dan kepemilikan SIM. Faktor lingkungan berhungan dengan kemacetan di jalan raya dimana suasana kemacetan dapat mempengaruhi emosi pengemudi (Tasca, 2000).

Masa remaja merupakan masa peralihan dari masa kanak-kanak menuju masa dewasa yang berlangsung antara usia 10-19 tahun. Masa peralihan yang dialami remaja akan berpengaruh terhadap pola pikir, sikap dan pola perilaku. Seorang remaja akan cenderung melakukan pencarian jati diri. Remaja yang melakukan pencarian jati diri akan cenderung berperilaku yang mengarah pada kesenangan sesaat tanpa memperhatikan norma yang berlaku di lingkungan sekitar (Depkes RI, 2001).

Klasifikasi remaja berdasarkan Depkes RI (2001) menyebutkan bahwa rentang usia siswa SMA termasuk dalam masa remaja penengahan dan akhir yang berlansung pada usia antara 14-19 tahun. Tujuan penelitian ini adalah untuk menganalisis hubungan antara agressive driving behavior pengemudi sepeda motor yang dengan kejadian kecelakaan lalu lintas pada siswa SMA di Kabupaten Sidoarjo tahun 2017.

\section{METODE PENELITIAN}

Penelitian ini merupakan penelitian observasional analitik dimana penelitian dilakukan dengan melakukan pengamatan tanpa memberikan perlakukan tertentu kepada subjek penelitian dengan tujuan 
untuk menganalisis hubungan antara agressive driving behavior dengan kejadian kecelakaan lalu lintas.

Rancang bangun yang digunakan dalam penelitian ini adalah kasus-kontrol karena penelitian ini mempelajari hubungan antara paparan (agressive driving behavior) dan kejadian kecelakaan dengan mengamati dan mempelajari paparan atau faktor risiko (agressive driving behavior) di masa lalu pada kelompok kasus dan kelompok kontrol.

Penelitian dilakukan di 4 SMA terdiri dari 2 SMA negeri dan 2 SMA swasta dan terletak di 3 Kecamatan di Kabupaten Sidoarjo yang letaknya didekat jalan raya dengan situasi kemacetan yang tinggi karena kemacetan dapat mempengaruhi tindakan agresif mengemudi dimana situasi macet dapat menimbulkan emosi pada pengemudi yang berakibat pada tindakan agresif mengemudi.

Populasi penelitian ini adalah semua siswa SMA berusia lebih besar sama dengan 17 tahun dan mengemudi sepeda motor yang terbagi dalam kelompok kasus dan kelompok kontrol. Kelompok kasus merupakan siswa SMA berusia lebih besar sama dengan 17 tahun dan mengemudi sepeda motor yang pernah mengalami kecelakaan lalu lintas dalam 1 tahun terakhir sedangkan yang tidak mengalami kecelakaan lalu lintas dalan 1 tahun terakhir termasuk dalam kelompok kontrol. Pengambilan data dilakukan pada bulan Desember 2017.

Sampel penelitian melibatkan sebanyak 72 responden yang terdiri dari 24 responden untuk kelompok kasus dan 48 responden untuk kelompok kontrol. Data kasus ditelusuri dari penelitian sebelumnya dalam satu wilayah yang sama yang dilakukan Nastiti (2017) dimana didapatkan 40 sampel kasus kecelakaan lalu lintas kemudian dipilih secara purposive berdasarkan lokasi sekolah dan diambil sebanyak 24 sampel kasus kecelakaan lalu lintas untuk diteliti. Sampel untuk kelompok kontrol dipilih dengan metode matching sample berdasarkan usia dan jenis kelamin dari kelompok kasus dari sekolah yang sama.

Variabel independent dalam penelitian ini adalah pengalaman mengemudi dan agressive driving behavior. Variabel dependen dalam penelitian ini adalah kejadian kecelakaan lalu lintas. Instrumen yang digunakan dalam penelitian ini menggunakan kuesioner adopsi dari ADBS (Agressive Driving Behavior Scale) oleh Houston, et al.(2003) yang mempunyai nilai reliabilitas $\alpha=0.80$ untuk 11 item pernyataan.

Analisis menggunakan statistik deskriptif untuk menjelaskan distribusi frekuensi masing-masing variabel berdasarkan riwayat kecelakaan. Uji statistik menggunakan chi-square $(\alpha=0.05)$ dengan tabel kontingensi $2 \times 2$. Hubungan keterkaitan antarvariabel dinyatakan dengan nilai $\mathrm{p}$ dan besar risiko dinyatakan dengan nilai Odd Ratio (OR) dengan Confidence Interval sebesar 95\%.

\section{HASIL}

Responden pada kelompok kasus terdiri dari 24 siswa SMA di Sidoarjo yang merupakan pengemudi sepeda motor yang berusia lebih besar sama dengan 17 tahun yang pernah mengalami kecelakaan lalu lintas sedangkan pada kelompok kontrol terdiri dari 48 siswa SMA di Sidoarjo pengemudi sepeda motor yang tidak pernah mengalami kecelakaan lalu lintas dalam 1 tahun terakhir di Kabupaten Sidoarjo. Responden yang terlibat dalam penelitian ini berusia 17 dan 18 tahun.

\section{Karakteristik Responden dalam Mengemudi}

Karakteristik responden dalam mengemudi dalam penelitian ini adalah keterampilan responden dalam mengemudi sepeda motor yang ditunjukkan dengan pengalaman dalam mengemudi. Pengalaman mengemudi dalam penelitian ini adalah lamanya respoden dalam menggunakan sepeda motor. 
Tabel 1. Distribusi Kecelakaan Lalu Lintas Berdasarkan Pengalaman dalam Mengemudi

\begin{tabular}{|c|c|c|c|c|}
\hline \multirow{3}{*}{$\begin{array}{l}\text { Pengalaman } \\
\text { mengemudi }\end{array}$} & \multicolumn{4}{|c|}{$\begin{array}{c}\text { Kecelakaan Lalu } \\
\text { Lintas }\end{array}$} \\
\hline & \multicolumn{2}{|c|}{ Pernah } & \multicolumn{2}{|c|}{$\begin{array}{c}\text { Tidak } \\
\text { Pernah }\end{array}$} \\
\hline & $\mathbf{n}$ & $\%$ & $\mathbf{n}$ & $\%$ \\
\hline$<1$ tahun & 0 & 0 & 1 & 2,08 \\
\hline 1 - 3 tahun & 7 & 29,2 & 13 & 25 \\
\hline$>3$ tahun & 17 & 70,8 & 35 & 72,9 \\
\hline Jumlah & 24 & 100 & 48 & 100 \\
\hline
\end{tabular}

Tabel 1 menunjukkan bahwa sebagian besar siswa SMA di Sidoarjo memiliki pengalaman mengemudi sepeda motor lebih besar 3 tahun. Pada kelompok kasus, siswa SMA yang pernah mengalami kecelakaan lalu lintas paling banyak memiliki pengalaman mengemudi sepeda motor lebih besar 3 tahun (70,8\%) dan pada kelompok kontrol siswa SMA yang tidak pernah mengalami kecelakaan lalu lintas juga sebagian besar memiliki pengalaman mengemudi sepeda motor lebih besar 3 tahun (72,9\%). Tabel 1 menunjukkan bahwa pengalaman mengemudi sepeda motor siswa SMA di Sidoarjo tidak dapat ditentukan sebagai penyebab terjadinya kecelakaan lalu lintas di Sidoarjo.

\section{Distribusi Agressive Driving Behavior Responden}

Pengukuran agressive driving behavior dikategorikan menjadi dua kategori yaitu kebiasaan agresif mengemudi tinggi dan kebiasaan agresif mengemudi rendah. Kategori agressive driving behavior tinggi adalah interval dari hasil perolehan skor antara nilai tertinggi dan nilai median sedangkan kategori agressive driving behavior rendah adalah interval dari hasil peroleh skor antara nilai terendah dengan nilai median.
Tabel 2. Distribusi Agressive Driving Behavior pada Siswa SMA di Sidoarjo

\begin{tabular}{lcc}
\hline \multirow{2}{*}{$\begin{array}{c}\text { Agressive Driving } \\
\text { Behavior }\end{array}$} & \multicolumn{2}{c}{ Jumlah } \\
\cline { 2 - 3 } & n & $\%$ \\
\hline $\begin{array}{l}\text { Agressive Driving } \\
\text { Behavior Tinggi }\end{array}$ & 39 & 54,2 \\
$\begin{array}{l}\text { Agressive Driving } \\
\text { Behavior Rendah }\end{array}$ & 33 & 45,8 \\
\hline Jumlah & 72 & 100 \\
\hline
\end{tabular}

Penilaian agressive driving behavior dari 72 siswa SMA di Sidoarjo diperoleh total skor dengan nilai maksimum atau nilai tertinggi yaitu 43 dan nilai terendah atau nilai minimum yaitu 14 dengan nilai median yaitu 14 . Kategori agressive driving behavior tinggi jika total skor yang diperoleh responden diantara 2643 sedangkan kategori kebiasaan agresif mengemudi rendah jika total skor yang diperoleh responden diantara 14-25. Tabel 2 menunjukkan bahwa siswa SMA di Sidoarjo lebih banyak memiliki agressive driving behavior yang tinggi $(54,2 \%)$.

\section{Hubungan antar variabel}

Tabel 3. Analisis Hubungan Antara Lama Mengemudi dengan Agressive Driving Behavior pada Siswa SMA di Sidoarjo

\begin{tabular}{|c|c|c|c|c|c|c|}
\hline \multirow{3}{*}{$\begin{array}{c}\text { Pengala } \\
\text { man } \\
\text { Mengem } \\
\text { udi }\end{array}$} & \multicolumn{4}{|c|}{ Agressive Driving } & \multirow{2}{*}{\multicolumn{2}{|c|}{ Jumlah }} \\
\hline & \multicolumn{2}{|c|}{ Tinggi } & \multicolumn{2}{|c|}{ Rendah } & & \\
\hline & $\mathbf{n}$ & $\%$ & $\mathbf{n}$ & $\%$ & $\mathbf{n}$ & $\%$ \\
\hline $\begin{array}{l}<1-3 \\
\text { tahun }\end{array}$ & 6 & 30 & 14 & 70 & 20 & 100 \\
\hline$>3$ tahun & 33 & 63,4 & 19 & 36,6 & 52 & 100 \\
\hline
\end{tabular}

Analisis hubungan antar variabel dalam penelitian ini dilakukan antara pengalaman mengemudi dengan agressive driving behavior dan agressive driving 
behavior dengan kejadian kecelakaan lalu lintas.

Tabulasi silang pada tabel 3 menunjukkan bahwa siswa SMA di Sidoarjo yang memiliki pengalaman mengemudi lebih besar 3 tahun lebih banyak memiliki kebiasaan agressive driving yang tinggi $(63,4 \%)$ sedangkan siswa SMA di Sidoarjo yang memiliki pengalaman mengemudi kurang dari 1-3 tahun lebih banyak memiliki agressive driving behavior yang rendah (70\%). Tabel 3 menunjukkan bahwa pengalaman mengemudi sepeda motor pada siswa SMA di Sidoarjo merupakan salah satu faktor yang dapat mempengaruhi agressive driving behavior. Hasil analisis chi-square menghasilkan nilai $p=0,022$ yang berarti terdapat hubungan antara lama mengemudi dengan agressive driving behavior pada siswa SMA di Sidoarjo. Nilai Odd Ratio (OR) sebesar 0,247 artinya pengemudi yang berpengalaman mengemudi kurang dari 1-3 tahun berpotensi melakukan agressive driving behavior 0,247 kali lebih rendah jika dibandingkan dengan pengemudi yang berpengalaman mengemudi lebih besar 3 tahun.

Tabel 4. Analisis Hubungan Antara Agressive Driving Bahavior dengan Kejadian Kecelakaan Lalu Lintas pada Siswa SMA di Sidoarjo

\begin{tabular}{lcccc}
\hline \multirow{2}{*}{$\begin{array}{c}\text { Agressive } \\
\text { Driving } \\
\text { Behavior }\end{array}$} & \multicolumn{2}{c}{ Kecelakaan Lalu Lintas } \\
\cline { 2 - 5 } & Pernah & \multicolumn{2}{c}{$\begin{array}{c}\text { Tidak } \\
\text { Pernah }\end{array}$} \\
\cline { 2 - 5 } & $\mathbf{n}$ & $\%$ & $\mathbf{n}$ & $\%$ \\
\hline Tinggi & 19 & 79,2 & 20 & 41,7 \\
Rendah & 5 & 20,8 & 28 & 58,3 \\
\hline Jumlah & 24 & 100 & 48 & 100 \\
\hline
\end{tabular}

Tabel 4 menunjukkan bahwa siswa SMA di Sidoarjo yang pernah mengalami kecelakaan lalu lintas lebih banyak memiliki kebiasaan agressive driving yang tinggi (79,2\%) sedangkan siswa SMA yang tidak pernah mengalami kecelakaan lalu lintas lebih banyak memiliki kebiasaan agressive driving yang rendah (58,3\%). Tabel 4 menunjukkan bahwa agressive driving behavior pada siswa SMA di Sidoarjo merupakan salah satu penyebab terjadinya kecelakaan lalu lintas di Sidoarjo. Hasil analisis chi-square menghasilkan nilai $p=0,006$ yang berarti terdapat hubungan antara agresisve driving behavior pengemudi sepeda motor dengan kejadian kecelakaan lalu lintas pada siswa SMA di Sidoarjo. Nilai Odd Ratio (OR) sebesar 5,320 $(95 \% \mathrm{CI}=1,701-16,635)$ artinya pengemudi sepeda motor yang memiliki agressive driving behavior yang tinggi akan beresiko 5,320 kali lebih besar mengalami kecelakaan sepeda motor jika dibandingkan dengan pengemudi yang memiliki kebiasaan agresif mengemudi yang rendah.

\section{Faktor Agressive Driving Behavior yang Paling Dominan Pada Siswa SMA di Sidoarjo Berdasarkan Frekuensi}

Pengukuran agressive driving behavior menggunakan kuesioner yang diadopsi dari ADBS (Agressive Driving Behavior Scale) oleh Houston, et al. (2003) yang terdiri dari dua kategori yaitu kategori conflict behavior yang terdiri dari 7 pernyataan termasuk kebiasaan membuntuti (taigaiting), mengklakson (honking), melakukan gerakan/isyarat kasar (rude gesturing) dan mengedipkan lampu jauh di suasana yang tenang (flashing light) dan kategori speeding yang terdiri dari 4 item pernyataan. Faktor-faktor agressive driving behavior yang paling dominan dapat ditunjukkan dengan jumlah responden yang paling banyak dalam melakukan agressive driving behavior yang dapat dilihat pada tabel 5 .

Tabel 5 menunjukkan bahwa faktor yang paling dominan yang biasa dilakukan siswa SMA di Sidoarjo dalam melakukan agressive driving behavior pada kategori conflict behavior adalah membunyikan klakson ketika kesal dengan pengemudi lain $(72,2 \%)$. Pada kategori 
speeding faktor yang paling dominan yang biasa dilakukan siswa SMA di Sidoarjo dalam melakukan agressive driving behavior adalah mempercepat kendaraan ketika akan didahului oleh pengemudi lain $(75 \%)$.

Tabel 5. Distribusi Frekuensi Faktor Agressive Driving yang Dominan Pada Siswa SMA Berdasarkan Frekuensi

\begin{tabular}{|c|c|c|c|c|c|c|}
\hline \multirow{3}{*}{ Faktor Agressive Driving } & \multicolumn{4}{|c|}{ Agressive Driving } & \multirow{2}{*}{\multicolumn{2}{|c|}{ Jumlah }} \\
\hline & \multicolumn{2}{|c|}{ Tinggi } & \multicolumn{2}{|c|}{ Rendah } & & \\
\hline & $\mathbf{n}$ & $\%$ & $\mathbf{n}$ & $\%$ & $\mathbf{n}$ & $\%$ \\
\hline \multicolumn{7}{|c|}{ Conflict Behavior } \\
\hline Menekan rem dengan sengaja & 19 & 26,4 & 53 & 73,6 & 72 & 100 \\
\hline $\begin{array}{l}\text { Mengemudi dengan memberikan isyarat/gerakan } \\
\text { kasar ketika kesal dengan pengemudi lain }\end{array}$ & 15 & 20,8 & 57 & 79,2 & 72 & 100 \\
\hline $\begin{array}{l}\text { Membunyikan klakson ketika kesal dengan } \\
\text { pengemudi lain. }\end{array}$ & 52 & 72,2 & 20 & 27,8 & 72 & 100 \\
\hline $\begin{array}{l}\text { Mengikuti kendaraan lain yang melaju dengan } \\
\text { jarak yang sangat dekat }\end{array}$ & 19 & 26,4 & 53 & 73,6 & 72 & 100 \\
\hline $\begin{array}{l}\text { Mendahului/menyalip diantara kendaraan yang } \\
\text { menjaga jarak. }\end{array}$ & 28 & 38,9 & 44 & 61,1 & 72 & 100 \\
\hline $\begin{array}{l}\text { Mengikui kendaraan lain dengan jarak yang } \\
\text { sangat dekat. }\end{array}$ & 31 & 43,1 & 41 & 56,9 & 72 & 100 \\
\hline $\begin{array}{l}\text { Mengedipkan lampu jauh pada saat yang tidak } \\
\text { dibutuhkan. }\end{array}$ & 34 & 47,2 & 38 & 52,8 & 72 & 100 \\
\hline
\end{tabular}
Speeding

Mempercepat kendaraan ketika akan didahului oleh pengemudi lain.

Mengebut pada saat lalu lintas padat

Melewati/mendahului kendaraan lain dengan jarak yang sangat sempit.

Mempercepat kendaraan diperempatan saat lampu lalu lintas berubah dari kuning ke merah.

$\begin{array}{cccccc}54 & 75 & 18 & 25 & 72 & 100 \\ 34 & 47,2 & 38 & 52,8 & 72 & 100 \\ 31 & 43,1 & 41 & 56,9 & 72 & 100 \\ 22 & 30,6 & 50 & 69,4 & 72 & 100\end{array}$

\section{PEMBAHASAN}

\section{Karakteristik responden dalam mengemudi}

Distribusi kecelakaan lalu lintas berdasarkan pengalaman mengemudi pada siswa SMA di Sidoarjo bahwa yang memiliki pengalaman mengemudi sepeda motor lebih dari 3 tahun lebih banyak mengalami kecelakaan lalu lintas jika dibandingkan dengan siswa SMA yang memiliki pengalaman mengemudi sepeda motor kurang dari 1-3 tahun. Pengalaman, pengetahuan, dan persepsi mengenai kemampuan mengendalikan risiko untuk menghindari kecelakaan lalu lintas saat mengemudi sebanding dengan sering tidaknya seseorang mengemudi kendaraan (Salihat et al., 2010).

Fase sebelum kecelakaan berdasarkan Haddon's Matrix merupakan upaya pencegahan terjadinya kecelakaan lalu lintas. Pada faktor manusia, kecelakaan lalu lintas dapat disebabkan oleh kurangnya informasi yang didapatkan, ketidakmampuan dalam mengemudi kendaraan dan kurangnya pembinaan oleh polisi (Mohan et al., 2006).

Pengalaman mengemudi sepeda motor pada siswa SMA di Sidoarjo pada penelitian ini tidak dapat membuktikan bahwa pengetahuan dan keterampilan 
mengemudikan sepeda motor di jalan raya dapat menekan risiko terjadiya kecelakaan lalu lintas.

Penerapan matriks Haddon pada kasus kecelakaan sepeda motor di Kota depok dalam penelitan Sari (2012) menyebutkan bahwa faktor penyebab kecelakaan pada faktor manusia disebabkan karena pengemudi yang tidak terampil, tidak tertib dan lengah. Satlantas Kabupaten Malang menyebutkan bahwa kecelakaan lalu lintas seringkali terjadi didahului oleh pelanggaran lalu lintas (Marsaid, 2010).

Penelitian ini melibatkan siswa SMA sebagai responden yang berusia 17 dan 18 tahun dimana usia tersebut termasuk dalam masa remaja pada tahap akhir. Kecelakaan lalu lintas pada remaja lebih banyak disebabkan karena pelanggaran lalu lintas. Bentuk pelanggaran yang sering dilakukan remaja adalah tidak lengkapnya surat-surat mengemudi, pelanggaran marka dan pelanggaran rambu-rambu lalu lintas (Safitri et al., 2013).

Karakteristik siswa SMA di Sidoarjo dalam mengemudi di jalan raya dimungkinkan karena tidak memiliki SIM dan melakukan pelanggaran rambu-rambu lalu lintas. Kecelakaan lalu lintas yang terjadi pada siswa SMA di Sidoarjo kemungkinan disebabkan karena perilaku yang melanggar peraturan lalu lintas. Berdasarkan hasil observasi lingkungan, kepadatan lalu lintas pada pagi hari yaitu antara jam 06.00-08.00 menyebabkan siswa SMA terburu-buru dalam mengemudi dan melanggar rambu lalu lintas agar cepat sampai di sekolah.

Sejalan dengan penelitian Marsaid (2010) tentang faktor yang berhubungan dengan kejadian kecelakaan di Kabupaten Malang menyebutkan bahwa perilaku tidak tertib pada pengemudi sepeda motor yang paling banyak dilakukan adalah pelanggaran rambu-rambu lalu lintas dimana pengemudi mengebut karena terburu-buru ingin sampai pada tempat tujuan sehingga beresiko membahayakan pihak lawan.

\section{Hubungan antara Pengalaman Mengemudi dengan Agressive Driving Behavior}

Aggressive driving behavior dipengaruhi oleh beberapa faktor yaitu usia, jenis kelamin, faktor sosial, kepribadian, gaya hidup, keterampilan mengemudi dan faktor lingkungan (Tasca, 2000).

Hasil penelitian ini menunjukkan bahwa siswa SMA yang memiliki kebiasaan agresif mengemudi yang tinggi sebagian besar memiliki pengalaman mengemudi selama lebih dari 3 tahun daripada responden yang memiliki pengalaman bekendara kurang dari 1-3 tahun. Hasil analisis hubungan antara lama mengemudi dengan tindakan agresif mengemudi menyatakan bahwa terdapat hubungan antara lama mengemudi dengan tindakan agresif mengemudi pada siswa SMA di Sidoarjo.

Setiap pengemudi sebagai pengguna jalan memerlukan pengetahuan dan keterampilan dalam mengemudikan kendaraan bermotor terkait aspek keselamatan mengemudi. Pengemudi dengan pengalaman yang minim dan kurangnya keterampilan dalam mengemudi dengan aman berisiko tinggi untuk mengalami kecelakaan lalu lintas dan cedera (Hidayati, 2015). Pengemudi yang mempunyai pengalaman dalam mengemudi sepeda motor cukup lama, kemungkinan untuk agresif cukup tinggi dibandingkan dengan pengemudi pemula, selain itu untuk mengemudi secara agresif dibutuhkan kemahiran (Sahabdin et al., 2010). Penelitian ini dapat membuktikan bahwa semakin lama pengemudi memiliki pengalaman dalam mengemudikan sepeda motor maka akan berpotensi memiliki agressive driving behavior. Pengalaman mengemudi sepeda motor yang lebih lama pada siswa SMA di Sidoarjo dengan agressive driving behavior yang tinggi menunjukkan bahwa agresifitas megemudi 
membutuhkan pengalaman dan kemahiran dalam mengemudikan sepeda motor di jalan raya.Pengalaman mengemudi yang mempengaruhi tindakan agressive driving seseorang dapat disebabkan oleh situasi lalu lintas. Seseorang yang merasa terhambat proses mengemudinya akan cenderung bertindak agresif dalam berkendara. Pengemudi yang merasa memiliki keterampilan dan tidak berorientasi pada keselamatan pada saat mengoperasikan kendaraan lebih sering menunjukkan kemarahan pada saat mengalami hambatan di jalan raya (Tasca, 2000).

Siswa SMA di Sidoarjo yang memiliki pengalaman mengemudi lebih lama yang memiliki agressive behavior yang tinggi dimungkinkan karena kematangan emosi yang belum stabil sehingga dalam mengahadapi situasi lalu lintas yang padat mengakibatkan mereka berperilaku agresif dalam mengemudi.

Disiplin remaja dalam berlalu lintas banyak dipengaruhi oleh faktor kematangan emosi remaja itu sendiri. Hal ini mengakibatkan remaja-remaja banyak yang melampiaskan rasa emosionalnya dengan cara berperilaku aggressive driving di jalanan dalam mengemudi (Utari, 2016).

\section{Hubungan Agressive Driving Behavior dengan Kejadian Kecelakaan Lalu lintas}

\footnotetext{
Pelanggaran terhadap lalu lintas dan agressive driving behavior berhubungan secara signifikan dengan terjadinya kecelakaan lalu lintas. Sikap aman dalam mengemudi (safety riding) berpengaruh dalam perilaku melanggar dan perilaku agresif mengemudi, dimana pengemudi yang memperhatikan keselamatan mengemudi dinilai cenderung tidak melakukan pelanggaran dan perilaku agresif dalam mengemudi (Yao, et al, 2011).

Kebiasaan agresif mengemudi berpengaruh dalam terjadinya kecelakaan lalu lintas. kebiasaan agresif mengemudi berhubungan dengan persepsi kecelakaan
}

dimana seseorang yang mempunyai persepsi risiko kecelakaan yang tinggi maka perilaku agresif mengemudinya cenderung rendah sedangkan seseorang yang mempunyai persepsi risiko kecelakaan yang rendah cenderung berperilaku agresif mengemudi yang tinggi (Utami, 2010).

Hasil penelitian ini menunjukkan bahwa siswa SMA yang melakukan agresif mengemudi yang tinggi lebih banyak mengalami kecelakaan lalu lintas daripada yang melakukan agresif mengemudi yang rendah. Hasil analisis hubungan antara kebiasaan agresif mengemudi dengn kejadian kecelakaan sepeda motor menyatakan bahwa terdapat hubungan yang signifikan antara tindakan agresif mengemudi dengan kejadian kecelakaan sepeda motor.

Contantinou, et al. (2011) menyebutkan bahwa faktor agresif mengemudi berkorelasi positif dengan pelanggaran dan kecelakaan lalu lintas. Perilaku mengebut merupakan problem budaya berlalu lintas di beberapa negara, seperti di Finlandia dan Iran bahwa ditemukan hubungan yang signifikan antara pelanggaran perilaku agresif mengemudi dengan angka kejadian kecelakaan lalu lintas (Ozkan, et al., 2006). Agressive driving behavior pada siswa SMA di Sidoarjo dapat membuktikan bahwa perilaku yang tidak aman dalam berkendara dapat menyebabkan terjadinya kecelakaan lalu lintas. Faktor lain yang menjadi penyebab adalah karena padatnya kendaraan dijalan terutama pengemudi sepeda motor sehingga menimbulkan perilaku agressive driving yang tinggi.

Siswa SMA di Sidoarjo yang dimungkinkan karena tidak memiliki persepsi kecelakaan yang tinggi sehingga mereka bertindak agresif di jalan raya tanpa memperhatikan keselamatan berlalu lintas. Hal tersebut mengakibatkan tingginya angka kecelakaan lalu lintas di Sidoarjo. Selain itu manajemen waktu yang kurang akan menimbulkan potensi siswa 
SMA di Sidoarjo dalam melakukan pelanggaran ramb-rambu lalu lintas dan bertindak agresif saat mengemudi.

AAA fondation (2009) menyatakan bahwa lebih dari $67 \%$ korban meninggal akibat kecelakaan lalu lintas adalah pengemudi kendaraan bermotor yang melakukan tindakan agresif mengemudi.

Siswa SMA di Sidoarjo yang memiliki kebiasaan agresif bekendara tinggi memiliki risiko 5,320 kali lebih tinggi mengalami kecelakaan sepeda motor dibandingkan dengan pengemudi yang memiliki kebiasaan agresif mengemudi yang rendah.

\section{Faktor yang Dominan dalam Agressive Driving Behavior}

Kondisi lingkungan merupakan salah satu faktor yang dapat mempengaruhi agressive driving behavior. Shinar menjelaskan bahwa terdapat hubungan yang signifikan antara kondisi lingkungan dan tindakan agresif pada saat mengemudi (Tasca, 2000). Penelitian ini dilakukan pada lokasi dengan kemacetan yang tinggi dan pada lokasi sekolah yang berada di dekat jalan raya.

Faktor yang paling dominan yang dilakukan oleh siswa SMA dalam melakukan agressive driving dalam penelitian ini berdasarkan pengukuran menggunakan kuesioner ADBS (Agressive Driving Behavior Scale) adalah membunyikan klakson ketika merasa kesal dengan pengemudi lain pada kategori conflict behavior dimana pengemudi yang melakukan agressive driving dapat memicu terjadinya konflik dengan pengemudi lain. Pada kategori speeding dimana pengemudi mengebut ketika mengemudi di jalan raya menunjukkan bahwa faktor yang paling dominan yang dilakukan siswa SMA adalah mempercepat kendaraan ketika akan didahului oleh pengemudi lain.

Lajunen menjelaskan bahwa kemacetan dapat menimbulkan emosi marah pada pengemudi yang berakibat pengemudi tersebut melakukan aggressive driving (Tasca, 2000). Penelitian lain yang dilakukan oleh Luthfie (2014) tentang pengaruh self control dan moral disangement terhadap agressive drivng pada pengemudi sepeda motor menyebutkan bahwa self control berpengaruh signifikan terhadap agressive driving dan moral disangement memiliki pengaruh signifikan terhadap agressive drivng pada pengemudi sepeda motor. Self control dan moral disangement yang dimaksudkan adalah tindakan dengan kontrol diri yang minim seperti mengebut, membuntuti kendaraan, ugal-ugalan dan tindakan yang berisiko menyebabkan kecelakaan sepeda motor.

Penelitian Utari (2016) tentang hubungan aggressive driving dan kematangan emosi dengan disiplin berlalu lintas pada remaja pengemudi sepeda motor bahwa terdapat hubungan yang signifikan antara aggresive driving dan kematangan emosi remaja dengan disiplin berlalu lintas. Selain itu, kemungkinan lain penyebab seseorang melakukan agressive driving adalah usia remaja dan jenis kelamin. Parry menjelaskan bahwa agressive driving sebagian besar melibatkan pengemudi laki-laki dengan usia muda, yaitu antara 17-35 tahun, sedangkan dalam rentang usia yang sama, pengemudi perempuan menujukkan tingkat yang lebih rendah (Tasca, 2000).

Siswa SMA dalam usia remaja tahap akhir memiliki emosi yang belum matang dan kontrol diri yang masih labil, sehingga dengan kondisi kemacetan dijalan raya memungkinkan mereka untuk melakukan agressive driving.

\section{SIMPULAN}

Kesimpulan dari penelitian ini adalah karakteristik siswa SMA yang terlibat dalam penelitian ini berdasarkan kasus kecelakaan lalu lintas bahwa sebagian besar siswa SMA di Sidoarjo yang mengalami kecelakaan lalu lintas 
memiliki pengalaman mengemudi lebih dari 3 tahun.

Penilaian terhadap Agressive driving behavior menunjukkan bahwa sebagian besar siswa SMA di Sidoarjo memiliki Agressive driving behavior. Pengalaman mengemudi pada siswa SMA di Sidoarjo dengan Agressive driving behavior berhubungan secara signifikan dimana siswa yang memiliki Agressive driving behavior yang tinggi lebih banyak dilakukan oleh siswa SMA di Sidoarjo yang memiliki pengalaman mengemudi selama lebih dari 3 tahun.

Agressive driving behavior berhubungan secara signifikan dengan kejadian kecelakaan lalu lintas pada siswa SMA di Sidoarjo dimana siswa SMA yang memiliki Agressive driving behavior yang tinggi lebih banyak mengalami kecelakaan lalu lintas jika dibandingkan dengan siswa SMA yang memiliki Agressive driving behavior yang rendah. Pengemudi sepeda motor yang memiliki Agressive driving behavior yang tinggi memiliki risiko mengalami kecelakaan lalu lintas jika dibandingkan dengan pengemudi yang memiliki Agressive driving behavior yang rendah.

Agressive driving behavior dapat disebabkan oleh salah satunya faktor lingkungan yaitu kemacetan. Hasil penelitian menunjukkan bahwa faktor Agressive driving behavior yang paling dominan yaitu pengemudi memiliki kebiasaan membunyikan klakson ketika merasa kesal dengan pengemudi lain dan pengemudi mempercepat kendaraan ketika akan didahului oleh pengemudi lain.

Upaya yang dapat dilakukan dalam mengurangi kebiasaan agresif mengemudi dan meminimalisir angka kejadian kecelakaan lalu lintas bagi pengemudi adalah dengan memanajemen waktu agar tidak terburu-buru ketika mengemudi dan memprioritaskan keselamatan dalam mengemudi serta mengontrol emosi saat bekendara.

Pihak sekolah dan instansi kepolisian dapat bekerja sama untuk menghimbau siswa dan siswi di sekolah untuk berkendara selamat dengan mengutamakan safety riding serta memberikan sanksi tegas bagi pelanggar peraturan lalu lintas. Selain itu, peran orang tua sangat penting untuk menghimbau putra putri nya agar menerapkan disiplin dalam berkendara serta memberikan pendidikan tentang keselamatan berkendara.

\section{DAFTAR PUSTAKA}

AAA Fondation, 2009. Agressive Driving: Research Update. AAA Fondation for Traffic Safety, Washington, DC.

Badan Intelijen Negara, 2013. Kecelakaan Lalu Lintas Menjadi Pembunuh Terbesar Ketiga. (online)

BPS Provinsi Jawa Timur, 2014. Provinsi Jawa Timur dalam Angka 2013. Katalog BPS: 1102001.35 . Surabaya: CV. Media Konstruksi

Constantinou, E., Panayiotou, G., Kontantinou, N., 2011. Risky and aggressive driving in young adults: Personality matters. Accident Analysis and Prevention, 43 (2011) 1323-1331

Danang, 2010. Budaya Tertib Lalu Lintas. Jakarta: Sarana Bangun Pustaka

Depkes RI, 2001. Pedoman Jiwa Remaja: Pegangan bagi Dokter Puskesmas. Jakarta: Depkes dan Depsos RI Dirjen Kesmas Depkes

Hidayati, A., 2015. Hubungan Jenis Kelamin dan Faktor Perilaku Pengemudi Sepeda Motor dengan Kecelakaan Lalu Lintas di Kecamatan Wonokromo Surabaya pada Siswa SMP Tahun 2015. Skripsi. Surabaya: Universitas Airlangga.

Houston, Harris dan Norman, 2003. The Aggressive Driving Behavior Scale: Developing a Self-Report Measure of Unsafe Driving Practices. North American Journal 
of Psychology (2003), Vol. 5, No. 2, 269-278

Korlantas Polri, 2017. Statistik Kecelakaan Lalu Lintas (online).

KNKT, 2016. Data Investigasi Kecelakaan LLAJ Tahun 2010-2016.

Luthfie, A., 2014. Pengaruh Self Control dan Moral Disangement terhadap Agressive Driving pada Pengemudi Sepeda Motor. Skripsi. Jakarta: UIN Syarif Hidayatullah Jakarta

Marsaid, Hidayat, M., Ahsan, 2013. Faktor yang Berhubungan dengan Kejadian Kecelakaan Lalu Lintas pada Pengemudi Sepeda Motor di Wilayah Polres Kabupaten Malang. Jurnal Ilmu Keperawatan, Vol. 1 No. 2 Hal: 98-112.

Mohan, D., Tiwari, G., Khayesi, M., Nafukho, F.M., 2006. Road Traffic Injury Prevention: Training Manual. India: WHO.

Nastiti, F. A., 2017. Hubungan Jenis Kelamin, Kepemilikan SIM dan Pengetahuan Mengemudi dengan Kejadian Kecelakaan Lalu Lintas (Studi Di Kabupaten Sidoarjo Pada Pelajar SMA Tahun 2017). Skripsi. Surabaya: Universitas Airlangga

Ozkan, T., Lajunen, T., et al, 2006. Crosscultural differences in driving behaviours: A comparison of six countries. Transportasion Reearch Part F. F (2006) 227-242.

Safitri, A., Rahman, T., 2013. Tingkat Kepatuhan Hukum Siswa SMA Kartika IV-3 Surabaya Terhadap Etika Berlalu Lintas Menurut Undang-Undang Lalu Lintas dan AngkutanJalan. Skripsi. Surabaya: Universitas Negeri Surabaya

Sahabudin, H. Wartatmo, Kuschitawati, S., 2010. Pengemudi sebagai Faktor Risiko Terjadinya Kecelakaan Lalu Lintas Sepeda Motor Tahun 2010. Berita Kedokteran Masyarakat,
Vol. 27 No. 2 Hal. 84-100, Juni 2011

Salihat, I. K., Kurniawidjaja, L.M., 2010. Persepsi Risiko Mengemudi dan Perilaku Penggunaan Sabuk Keselamatan di Kampus Universitas Indonesia, Depok. Jurnal Kesehatan Masyarakat Nasional, Vol. 4 No. 6 Hal: 275280.

Sari, K.D.M., 2012. Model Hubungan Penyebab Kecelakaan Lalu Lintas Sepeda Motor di Kota Depok. Tesis. Jakarta: Universitas Indonesia

Tasca, L., 2000. A Review of The Literature on Agressive Driving research. Road User Safety Branch.

Utami, N., 2010. Hubungan Persepsi Risiko Kecelakaan dengan Aggressive Driving Pengemudi Motor Remaja. Skripsi. JakartaUniversitas Islam Negeri Syarif Hidayatullah.

Utari, 2016. Hubungan Agressive Driving dan Kematangan Emosi dengan Disiplin Berlalu Lintas pada Remaja Pengemudi Sepeda Motor di Samarinda. ejournal Psikologi, 4(3), pp. 352-260.

Utari, C. G., 2010. Hubungan Pengetahuan, Sikap, Persepsi dan Keterampilan Mengendara Mahasiswa Terhadap Perilaku Keselamatan Mengemudi (Safety Riding) di Universitas Gunadarma Bekasi Tahun 2009. Skripsi. Jakarta: UIN Syarif Hidayatullah

WHO, 2013. Global Status On Road Safety 2013. Prancis: WHO.

Yao, L., Wu, C., 2012. Traffic Safety for Electric Bike Riders in China Attitudes, Risk Perception, and Aberrant Riding Behaviors. Journal of the Transportation Research Board. 